\title{
IMPLEMENTASI PERATURAN DAERAH NO 3 TAHUN 2009 TENTANG KETENTRAMAN DAN KETERTIBAN UMUM DALAM RANGKA MEMBANGUN GENERASI MUDA SADAR BUDAYA DI NAGARI KATAPING KECAMATAN BATANG ANAI KABUPATEN PADANG PARIAMAN
}

\author{
Annisa Fitri \\ Ilmu Administrasi Negara \\ Fakultas Ilmu Sosial dan Ilmu Politik Universitas Ekasakti Padang \\ fitriannisa@unespadang.ac.id
}

\begin{abstract}
ABSTRAK
Dengan munculnya berbagai permasalahan yang ada, pemerintah berupaya untuk melakukan pengaturan terhadap kegiatan-kegiatan yang dinilai mengganggu aktivitas masyarakat atau ketertiban umum. Adapun Permasalahan yang diangkat dalam penelitian ini adalah Bagaimana Implementasi Peraturan Daerah No 3 tahun 2009 tentang Ketentraman dan Ketertiban Umum Dalam Rangka Membangun Generasi Muda Sadar Budaya Di Nagari Katapiang Kecamatan Batang Anai Kabupaten Padang Pariaman, Kendala apa saja yang ditemui dalam Implementasi Peraturan tersebut serta Upaya apa saja yang dilakukan untuk mengatasi kendala itu. Metode penelitian yang digunakan dalam penelitian ini adalah deskriptif kualitatif dengan pendekatan yuridis sosiologis, yang menjadi populasi dalam penelitian ini adalah seluruh Perangkat Nagari, Bundo Kanduang, Tungku Tigo Sajarangan dan seluruh masyarakat yang ada di Kanagarian Katapiang Kecamatan Batang Anai Kabupaten Padang Pariaman. Teknik pengambilan sampelnya berdasarkan purpose sampling dengan jumlah sampel 15 orang. Peraturan Daerah Kabupaten Padang Pariaman No. 3 Tahun 2009 yang mengatur tentang ketentraman dan Ketertiban Umum Nagari Katapiang dilaksanakan dalam tiga tahapan kegiatan yang berlangsung secara terus menerus, yaitu: Tahap Sosialisasi, Tahap Pelaksanaan dan Tahap Monitoring. Kendala yang ditemui dalam Implementasi Kebijakan ini adalah Kurangnya Sosialisasi, Rendahnya kesadaran dan pemahaman hukum masyarakat, Keterbatasan sumber daya manusia dalam penegakan hukum, tidak adanya sanksi dari nagari untuk memberikan efek jera, rendahnya kesadaran pemuda terhadap pelestarian dan akulturasi adat istiadat serta nilai-nilai budaya, tidak dilibatkannya anak-anak muda (Generasi Muda) dalam pengambilan keputusan. Upaya yang dilakukan untuk mengatasi kendala tersebut dengan Memfokuskan sosialisasi kepada generasi muda melalui peran serta Kerapatan Adat Nagari, Melakukan pembinaan dan pengawasan ketentraman dan ketertiban kepada masyarakat terutama anak-anak muda Nagari.Untuk itu penulis menyarankan institusi pemerintah lebih memperhatikan anak-anak muda dengan memberikan kesempatan dan ruang public untuk berpartisipasi dalam pengambilan keputusan serta memberikan
\end{abstract}


pemahaman kepada mereka melalui pelatihan-pelatihan untuk meningkatkan rasa memiliki dan kecintaan terhadap budaya.

\section{Kata Kunci : Implementasi Kebijkan, Sadar Budaya, Generasi Muda, Ketentraman dan Ketertiban umum}

\section{Pendahuluan}

Pemuda sebagai generasi penerus hanya mewarisi dan diharapkan agar menjaga kebudayaan. Namun di era sekarang ini nilai kebudayaan di dalam masyarakat telah mulai meluntur bahkan ada sebagian yang mulai menghilang. Sebagai generasi penerus hendaknya dapat mencintai dan melestarikan kebudayaan yang telah diwariskan dari dulu, agar nilai-nilai kebudayaan yang telah ada dapat diwariskan pada anak cucu nanti, karena pembentukan kebudayaan membutuhkan waktu yang amat sangat luar biasa lama sekali tidak hanya diciptakan dan dibentuk dalam waktu yang singkat dan pembentukan kebudayaan tersebut tidak semudah membalikkan telapak tangan yakni melalui proses waktu yang lama dan turun temurun dari nenek moyang. Dan saat ini, seperti yang kita semua telah sadari, kebudayaan daerah, mulai luntur tergantikan oleh kebudayaan barat yang di agung-agungkan oleh generasi muda.

Daerah Minangkabau memiliki keragaman yang bersumber dari adat, budaya dan agama yang berjalan seiring secara harmonis membentuk identitas masyarakat sebagai bentuk identitas lokal yang menginspirasi kehidupan dan interaksi sesama masyarakat yang berada didalamnya. Namun demikian, kebangkitan budaya lokal bukan berarti kembali sepenuhnya kepada tradisi lalu dan menolak realitas kekinian yang terus berubah.

kebanyakan apa yang dianggap tradisi di masa kini, telah melewati batas waktu dengan mengalami penyesuaian dengan perkembangan-perkembangan baru (Giddens, 2001) Konteks lokal masyarakat Minangkabau fungsi dan peran generasi muda diakui dan dijunjung tinggi dalam adat. Eksistensi ini Bahkan di ungkapkan dalam pepatah adat minangkabau yang berbunyi "Nan Mudo Pambimbiang Dunia Ancang-ancang dalam nagari yang artinya, pemuda harapan bangsa di tangan pemuda terletak maju mundurnya bangsa di masa depan.

Permasalahan yang makin hari makin menjadi adalah makin mundurnya moral masyarakat Minangkabau, terutama pada generasi muda. Sebenarnya kesadaran akan permasalahan ini sudah dirasakan oleh setiap unsur masyarakat Minangkabau, baik pemangku adat maupun pemerintah. Maka dari itu diperlukan upaya untuk mengembalikan nilai-nilai Minangkabau Generasi Muda yang sudah jauh dari nilainilai Minangkabau.

Bukan perkara mudah untuk menjadikan Generasi Muda Minangkabau yang Sadar Budaya, Meskipun terdapat program yang mengajak kepada kebaikan, sayangnya masih terdapat kebebasan dalam melakukan seperti dalam hal kebutuhan terhadap hiburan kerap bertentangan dengan Norma Hukum, Adat, dan Kesusilaan serta Agama seperti maraknya penyakit masyarakat, perjudian, minuman keras, 
pertunjukan orgen tungal yang tidak senonoh yang merusak moral anak nagari, balapan motor liar, kegaduhan malam hari, pergaulan bebas dan lain sebagainya yang menimbulkan keresahan di masyarakat.

Dengan munculnya berbagai permasalahan yang ada pemerintah berupaya untuk melakukan pengaturan terhadap kegiatan-kegiatan yang dinilai mengganggu aktivitas masyarakat atau ketertiban umum. Bentuk konkrit pengaturan tersebut adalah dengan membentuk peraturan daerah dalam rangka mengatasi masalah ketertiban umum.

Berdasarkan Pasal 12 ayat (1) Undang-Undang Nomor 23 Tahun 2014 tentang Pemerintahan Daerah (UU No. 23 Tahun 2014), ketentraman dan ketertiban umum merupakan kewenangan Pemerintah Daerah sebagai Urusan Pemerintahan Wajib yang berkaitan dengan pelayanan dasar. Kewenangan Pemerintah Kabupaten/Kota dalam ketentraman dan ketertiban umum antara lain meliputi:

1. Penanganan gangguan ketentraman dan ketertiban umum dalam 1 (satu) Daerah kabupaten/kota;

2. Penegakan Perda Kabupaten/Kota dan peraturan bupati/walikota;

3. Pembinaan PPNS kabupaten/kota.

Dalam rangka melaksanakan kewenangan Pemerintah Daerah tersebut, diperlukan instrumen hukum yang mengatur aspek ketentraman dan ketertiban umum beserta ancaman sanksinya. Pemerintah Daerah pada umumnya membentuk Perda tentang Ketentraman dan Ketertiban Umum. Tidak terkecuali Pemerintah Kabupaten Padang Pariaman yang telah membentuk Peraturan Daerah Nomor 38 Tahun 2003 yang dirubah menjadi Peraturan Daerah Nomor 3 tahun 2009 tentang Ketertiban Umum dan Ketentraman Masyarakat

Tercapainya ketentraman dan ketertiban tersebut hanya dapat terjadi jika Perda No. 3 Tahun 2003 ini dalam penegakannya berjalan efektif. Namun penegakan sebuah peraturan perundang-undangan pada umumnya menemui hambatan. Selalu ada kesenjangan (gap) antara hukum dalam teks dan hukum dalam kenyataan di masyarakat.

Terkait konteks implementasi Perda No. 3 Tahun 2009, perlu diketahui sejauhmana implementasi penegakan Perda No. 3 Tahun 2009 di masyarakat. Penegakan Perda No. 3 Tahun 2009 harus dievaluasi agar dapat diidentifikasi hambatan dan kelemahan dalam penegakan Perda tersebut. Dengan demikian dapat diidentifikasi perubahan yang perlu dilakukan terkait penegakan Perda No. 3 Tahun 2009 agar tujuan ketentraman dan ketertiban di Kabupaten Padang Pariaman dapat tercapai. Misalnya dengan Memfokuskan Sosialisasi kepada generasi muda melalui peran serta Kerapatan Adat Nagari, melakukan pembinaan dan pengawasan ketentraman dan ketertiban kepada masyarakat terutama anak-anak muda Nagari, mengembangkan kualitas SDM melalui peningkatan peran lembaga Nagari, Revitalisasi (mengiatkan) organisasi kepemudaan Nagari, melakukan Koordinasi yang baik dengan Polisi, Satpol PP dan Masyarakat, Maka dari itulah penulis tertarik melakukan penelitian tentang Implementasi Peraturan Daerah No 3 Tahun 2009 tentang ketentraman dan ketertiban umum dalam rangka membangun generasi muda sadar budaya di Nagari Katapiang Kecamatan Batang Anai Kabupaten Padang 
Pariaman. Yang tujuannya adalah untuk mengetahui Bagaimana implementasi perda ini untuk membangun kesadaran budaya generasi muda dalam menjaga ketentraman dan ketertiban umum.

\section{Tinjauan Pustaka}

\subsection{Implementasi}

Menurut Patton dan Sawicki dalam Tangkilisan bahwa implementasi berkaitan dengan berbagai kegiatan yang diarahkan untuk merealisasikan program, dimana pada posisi ini eksekutif mengatur cara untuk mengorganisir, menginterpretasikan dan menerapkan kebijakan yang telah diseleksi. Sehingga dengan mengorganisir, seorang eksekutif mampu mengatur secara efektif dan efisien sumber daya, Unit-unit dan teknik yang dapat mendukung pelaksanaan program, serta melakukan interpretasi terhadap perencanaan yang telah dibuat, dan petunjuk yang dapat diikuti dengan mudah bagi realisasi program yang dilaksanakan.

Jadi tahapan implementasi merupakan peristiwa yang berhubungan dengan apa yang terjadi setelah suatu perundang-undangan ditetapkan dengan memberikan otoritas pada suatu kebijakan dengan membentuk output yang jelas dan dapat diukur. Dengan demikian tugas implementasi kebijakan sebagai suatu penghubung yang memungkinkan tujuan-tujuan kebijakan mencapai hasil melalui aktivitas atau kegiatan dan program pemerintah. (Tangkilisan, Hessel Nogi, 2003)

\subsection{Generasi Muda}

Persepsi tentang generasi muda yang berkembang dimasyarakat saat ini selalu berkaitan dengan konteks politik. Misalkan "generasi muda penerus bangsa". Penyematan kata tersebut sudah tidak asing lagi di masyarakat umum.

Sedangkan pada dasarnya kata generasi muda bisa diartikan sebagai masa peralihan dari anak anak menuju dewasa atau remaja dengan berkembangnya keadaan fisik dan non fisik. terutama yang paling berp engaruh adalah peralihan secara non fisik atau pola pikir, cara pandang dan emosional.

Mengenai persepsi yang berkembang di masyarakat tentang arti sessungguhnya kata "generasi muda" memang masih belum ada kesepakatan antara para ahli sosiologi. Tapi perlu diketahui, ada beberapa definisi atau pengertian generasi muda ditinjau dari beberapa kategori

Secara Biologis adalah mereka yang berusia 12-15 tahun ( remaja ) dan 15-30 tahun ( pemuda); Secara kebudayaan adalah mereka yang berusia 13-14 tahun. Secara Karir / Pekerjaan adalah adalah pekerja/ angkatan kerja yang berusia 18-22 tahun. Secara Idiologi politik adalah mereka yang berusia 18-40 tahun. Lembaga dan lingkungan hidup sosial Generasi muda dibedakan menjadi 3 kategori : Siswa 6-8 tahun, Mahasiswa, yakni usia 18-25 tahun. Dan Pemuda yang berada diluar sekolah / PT berusia 15-30 tahun.

\subsection{Budaya}

Slocum dalam West yang dikutip oleh M.Arifin mendefinisikan budaya sebagai asumsi-asumsi dan pola-pola makna yang mendasar, yang dianggap sudah selayaknya dianut dan dimanifestasikan oleh semua fihak yang berpartisipasi dalam organisasi. 
Budaya adalah sistem dari pola -pola tingkah laku yang diturunkan secara sosial yang bekerja menghubungkan komunitas ma nusia dengan lingkungan ekologi mereka. Dalam "cara-hidup-komuniti" ini termasuklah teknologi dan bentuk organisasi ekonomi, pola -pola menetap, bentuk pengelompokan sosial dan organisasi politik, kepercayaan dan praktek keagamaan, dan seterusnya. Bila budaya dipandang secara luas sebagai sistem tingkah laku yang khas dari suatu penduduk, satu penyambung dan penyelaras kondisi-kondisi badaniah manusia. (Arifin, 2010)

\subsection{Kesadaran Budaya}

Kesadaran budaya merupakan sikap dimana seseorang menghargai, memahami, dan mengerti akan adanya perbedaan-perbedaan yang ada dalam budaya tersebut. Kesadaran budaya ini tentu menjadi suatu hal yang teramat penting untuk kita benarbenar mengerti dan untuk kita pahami terkait dengan beragamnya kebudayaan yang ada di tiap masyarakat di sekitar kita. Hal ini karena banyaknya konflik yang terjadi akibat seseorang atau kelompok masyarakat yang tidak mengerti akan beragamnya dan begitu banyaknya masyarakat lain yang juga memiliki kebudayaan mereka sendiri. Mereka terkadang lupa bahwa kebudayaan itu terbentuk sesuai dengan corak masyarakat itu sendiri. Akan tetapi, mereka terkadang malah cenderung memperlakukan sama pada setiap bentuk kebudayaan.

\section{METODOLOGI PENELITIAN}

Metode penelitian ini adalah metode penelitian kualitatif yaitu penelitian tentang riset yang bersifat deskriptif dan cenderung menggunakan analisis dan pendekatan induktif. Hadari Nawawi menyatakan bahwa penelitian deskriptif adalah penelitian yang prosedur pemecahan masalahnya diselidiki dengan menggambarkan atau melukiskan keadaan subyek ataupun obyek penelitian (seseorang, lembaga masyarakat, dll) pada saat sekarang berdasarkan fakta-fakta yang tampak atau sebagaimana adanya yang meliputi interpretasi data dan analisis data. (Nawawi, 2012) Sedangkan Metode pendekatan yang akan Penulis gunakan dalam penelitian ini adalah pendekatan yuridis sosiologis. Pendekatan yuridis sosiologis adalah, artinya suatu penelitian yang dilakukan terhadap keadaan nyata masyarakat atau lingkungan masyarakat dengan maksud dan tujuan untuk menemukan fakta (fact-finding), yang kemudian menuju pada identifikasi (problem-identification) dan pada akhirnya menuju kepada penyelesaian masalah (problem-solution). (Maleong, 2002) Penelitian ini bertujuan untuk mendapatkan pemahaman yang sifatnya umum terhadap kenyataan sosial dari perspektif partisipan. Dengan populasi dalam penelitian ini adalah seluruh Perangkat Nagari, Bundo Kanduang, Tungku Tigo Sajarangan dan seluruh masyarakat yang ada di Kanagarian Katapiang Kecamatan Batang Anai Kabupaten Padang Pariaman. Sedangkan pengambilan Sample mengunakan teknik purpose samping yang berjumlah 15 orang, 7 orang dari perangkat nagari dan 8 orang dari masyarakat, untuk masyarakat penulis mengunakan kriteria berdasarkan umur yang dibagi kedalam dua golongan masyarakat yang berusia 15 - 30 Tahun dan masyarakat yang berusia diatas 30 Tahun. Teknik Pengumpulan Data melalui kepustakaan dan studi lapangan seperti wawancara, observasi dan dokumentasi

\section{HASIL DAN PEMBAHASAN}




\subsection{Implementasi Peraturan Daerah No 3 Tahun 2009 Tentang Ketentraman Dan Ketertiban Umum Dalam Rangka Membangun Generasi Muda Yang Sadar Budaya.}

Peraturan Daerah Kabupaten Padang Pariaman Nomor 3 Tahun 2009 tentang Perubahan atas Peraturan Daerah Kabupaten Padang Pariaman Nomor 38 Tahun 2003 tentang ketentraman dan ketertiban umum berisikan bahwa semakin maraknya penyalahgunaan minuman keras dapat mengganggu ketertiban umum dan menimbulkan ketidaktentraman dalam kehidupan soasial masyarakat; ketentuanketentuan dalam peraturan daerah nomor 38 tahun 2003 tentang ketentraman dan ketertiban umum belum dapat menjangkau pelaku perbuatan-perbuatan penyalahgunaan minuman keras; berdasarkan pertimbangan tersebut pada huruf a dan b dipandang perlu menetapkan peraturan daerah tentang perubahan atas Peraturan Daerah Kabupaten Padang Pariaman Nomor 38 tahun 2003 tentang ketentraman dan ketertiban umum. Peraturan Daerah ini mulai berlaku pada tanggal diundangkan; diundangkan pada tanggal 18 Mei 2009.

Berdasarkan hasil penelitian penulis terhadap Implementasi peraturan daerah padang pariaman no 3 tahun 2009 tentang ketentramana dan ketertiban umum terkait Perda tersebut:

Peraturan Daerah Kabupaten Padang Pariaman No. 3 Tahun 2009 yang mengatur tentang ketentraman dan Ketertiban Umum dilaksanakan dalam tiga tahapan kegiatan yang berlangsung secara terus menerus, yaitu: Tahap Sosialisasi, Tahap Pelaksanaan dan Tahap Monitoring. Masing-masing tahapan tersebut dapat dijelaskan, sebagai berikut:

\section{a. Tahap Sosialisasi}

Sosialisasi merupakan kegiatan penyebaran informasi mengenai keberadaan Perda No. 3 Tahun 2009 yang mengatur tentang ketentraman dan Ketertiban Umum di Kabupaten Padang Pariaman. Sosialisasi yang merupakan kegiatan awal dari serangkaian kegiatan pelaksanaan Perda ini dilakukan melalui dua cara, yaitu: secara langsung dan tidak langsung. Sosialisasi langsung dilakukan dalam bentuk penyuluhan di tingkat Kanagarian yang ada di Kabupaten Padang Pariaman, dan rata-rata hanya dilaksanakan satu kali penyuluhan di masing-masing Korong. Dalam kegiatan ini pihak-pihak yang diundang juga terbatas, yaitu : perwakilan dari kelompok masyarakat yang ada di Nagari, yaitu: perwakilan dari Tokoh-tokoh masyarakat seperti Niniak Mamak, Kaum Cadiak Pandai,Alim Ulama, Badan Permusyawaran Nagari dan perangkat Nagari dan Orang - orang yang berkepentingan lainnya.

Dengan demikian pelaksanaan penyuluhan kurang maksimal baik dari segi frekwensi, jangkauan pelaksanaan maupun pihak-pihak yang dilibatkan karena menurut hemat penulis kalau kita ingin melakukan sosialisasi tentunya akan melibatkan seluruh lapisan masyarakat, tetapi pada kenyataan yang ada didukung dengan hasil wawancara penulis dengan masyakat yang penulis golongkan sebagai pemuda mengatakan rata-rata menjawab mereka tidak tau tentang Perda ini karena tidak sampainya sosialisasi kepada mereka dikarenakan pemuda yang ada dinagari 
katapiang tidak dilibatkan dalam suatu kebijakan. Menurut pikiran penulis ini salah satu faktor kenapa pemuda itu banyak yang bersikap apatis dan pragmatis.

Sosialisasi tidak langsung dilakukan melalui media elektronik, Pemasangan Reklame dan penyebaran leaflet. Tapi pada kenyataannya tidak ada penyebaran leaflet maupun pemasangan Reklame di Nagari Katapiang tentang peraturan ini. Peraturan ini hanya dilakukan melalui mulut ke mulut dari masyarakat. Hal ini mengakibatkan rendahnya pemahaman masyarakat tentang maksud dari Perda itu sendiri.

\section{b. Tahap Pelaksanaan}

Sehubungan dengan Perda tersebut salah satu contoh yang memiriskan dari hari kehari yang sering terjadi yakni seperti yang terjadi tawuran antar Korong, keributan yang sering dibuat oleh orang luar atau tamu yang datang, Minuman-minuman Keras, Judi, Pertunjukan orgen yang diluar batas norma adat dan agama.

Dari segi pelaksanaan Peraturan ini belum terlaksana dengan baik karena masyarakat nagari Katapiang itu belum memiliki kesadaran tentang pentingnya mewujudkan keamanan dan ketertiban masyarakat, dengan menjaga lingkungan Korong masing-masing dari kejadian yang menggangu kehidupan bermasyarakat di Nagari Katapiang khususnya adalah Pemuda (generasi muda). Pemuda yang sering disebut rang nan mudo. Seharusnya kedudukan nan mudo itu menentukan pula kekuatannya sesuai fungsi yang diberikan adat. Fungsi nan mudo di Minang, membuat tepian menjadi elok, membuat visi nagari terwujud: "nagari menjadi aman dan damai" (nagari aman santoso). Kualitas perannya digambarkan adat: "kamanakan dipinang urang pulo" Artinya orang menoleh kepadanya, mencerminkan kualitas SDM Pemuda dalam budaya lokal Minangkabau. Tapi pada situasi sekarang jarang sekali pemuda nan manjago nagari hal itu disebabkan kurangnya pengetahuan dan didikan dari Mamak dan keluarga mereka. Kemudian dari segi pelaksanaan belum ada payung hukum dari nagari yang memberikan efek jera kepada masyarakat yang melakukan pelangaran.

Dengan adanya pelangaran yang sering terjadi maka dibutuhkanlah mitra kerja Nagari dengan Satpol PP dan Kepolisian, koordinasi merupakan kegiatan manajemen yang telah dilakukan secara rutin pada kantor Nagari. Wali Nagari menyadari bahwa tanpa koordinasi yang baik maka organisasi tidak akan berjalan secara efektif, meskipun demikian koordinasi yang dilakukan tentunya akan memiliki kendalakendala dimana maksud dan tujuan dari koordinasi adalah menyatupadukan semua unsur organisasi yang tentunya berbeda sehingga bekerjasama dalam pencapaian tujuan organisasi yang telah ditetapkan.

\section{c. Monitoring}

Monitoring merupakan kegiatan yang dilakukan oleh Pemerintah Daerah dalam memantau pelaksanaan Perda No. 3 Tahun 2009, untuk mengetahui sejauh mana Perda tersebut telah dilaksanakan. Meskipun kegiatan ini sangat penting bagi upaya peningkatan efektivitas pelaksanaan Perda, tetapi kegiatan yang seharusnya dilakukan secara rutin setiap akhir tahun ini belum dapat terlaksana dengan baik di Nagari 
Katapiang. Yang melaksanaan Monitoring itu adalah dari Pemerintah Daerah itu sendiri Kepada Nagari-Nagari maupun Pemerintah Nagari kepada Korong-korong.

Dari beberapa hasil wawancara dengan responden penulis menyimpulkan bahwa Implementasi dari Peraturan Daerah Padang Pariaman No 3 Tahun 2009 tentang ketentraman dan ketertiban umum khususnya di Nagari Katapiang, ada 3 tahap dari Implementasi Kebijakan tersebut pertama dilihat dari Tahap Sosialisasinya yang belum optimal baik secara langsung dan tidak langsung tidak melibatkan seluruh masyarakat karena sosialisasi ini pihak-pihak yang diundang terbatas pada pemangku kepentingan sehingga menyebabkan masyarakat khususnya pemuda (generasi muda) banyak yang bersikap apatis dan pragmatis terhadap peraturan. Yang kedua tahap pelaksanaannya Peraturan ini belum terlaksana dengan baik karena masyarakat khususnya adalah Pemuda (generasi muda) di Nagari Katapiang belum memiliki kesadaran tentang pentingnya mewujudkan keamanan dan ketertiban masyarakat, dengan menjaga lingkungan Korong masing-masing dari kejadian yang menggangu kehidupan bermasyarakat untuk itu Pemerintah Nagari membutuhkan mitra kerja Nagari dengan Satpol PP dan Kepolisian dalam pelaksanaannya Koordinasi baik dengan mitra kerja maupun dengan masyarakat sangat diperlukan. Yang ke tiga Tahap Monitoring pada tahap ini seharusnya dilakukan setiap akir tahun tapi pada kenyaannya tidak ada Pemerintahan Daerah maupun Pemerintahan Nagari melakukan Monitoring untuk mengetahui sejauh mana Perda tersebut telah dilaksanakan.

Jika kita kaitkan Peraturan Daerah ini dengan Kesadaran Pemuda terhadap budaya Minangkabau menurut penulis Peraturan ini sangat bagus untuk membangun generasi muda kita yang sadar akan budaya. Karena dalam konteks budaya, dimaksudkan sebagai seperangkat nilai, gagasan, norma yang menjadi pedoman berpikir, berucap, berperilaku, bertindak sesuai dengan yang diharapkan oleh sebagian besar warga masyarakat setempat.

Budaya masyarakat merupakan seperangkat nilai, gagasan, norma yang terbangun oleh budi dan daya warga masyarakat setempat dan telah terinternalisasi ke dalam alam kesadaran (mindset) secara turun temurun dan berfungsi sebagai pedoman yang menghubungkan antara aturan hukum pada tataran ide di satu pihak dan perilaku atau tindakan nyata pada tataran praksis di lain pihak yang diharapkan warga masyarakat.

Nilai yang dianut warga terhadap peraturan perundang-undangan, khususnya Perda No. 3 Tahun 2009, dapat dilihat pada pemikiran-pemikiran yang dikemukakan Masyarakat bahwa mereka sangat setuju dengan adanya peraturan ini. setidaknya peraturan ini dapat membudayakan orang minangkabau yang mana selama ini budaya minang telah dipengaruhi oleh budaya kebarat-baratan sehingga dengan adanya perda ini budaya minangkabau dapat terjaga hingga akhir zaman nanti.

4.2. Kendala apa saja yang ditemui dalam Implementasi Peraturan Daerah No 3 tahun 2009 tentang Ketentraman dan Ketertiban Umum Dalam Rangka Membangun Generasi Muda Sadar Budaya Di Nagari Katapiang Kecamatan Batang Anai 
Mengingat pelaksanaan suatu kebijakan merupakan kegiatan yang sifatnya interaktif, maka tidak bisa terlepas dari berbagai Kendala yang dapat mempengaruhi keberhasilan maupun kegagalan dalam pelaksanaannya. Demikian pula halnya, dalam implementasi Perda Kabupaten Padang Pariaman No. 3 Tahun 2009. Beberapa Kendala yang diidentifikasi menjadi penghambat implementasi Perda tersebut yaitu:

\section{Kurangnya Sosialisasi}

Pengetahuan penduduk Nagari Katapiang terhadap adanya Perda No.3 Tahun 2009 masih rendah. Berdasarkan wawancara Penulis terhadap 10 (sepuluh) orang responden tentang pengetahuan mereka terhadap Perda No. 3 Tahun 2009 ini, 7 (tujuh) di antaranya tidak mengetahui adanya Perda No. 3 Tahun 2009 rata-rata semuanya generasi muda. Hanya 3 (tiga) orang responden yang mengetahui adanya Perda ini yang mengatur tentang ketentraman dan ketertiban umum masyarakat di Nagari Katapiang, saat diwawancarai mereka mengakui bahwa tidak pernah mendapatkan dan mendengar adanya sosialisasi atau penjelasan dari pihak Pemerintahan Nagari mengenai ketentuan apa yang diatur dalam perda tersebut. Kondisi ini menunjukkan minimnya pengetahuan warga terhadap adanya Perda No. 3 Tahun 2009.

Kondisi ini juga menunjukkan bahwa sosialisasi Perda No. 3 Tahun 2009 masih belum menjangkau seluruh penduduk di Nagari Katapiang.

Sesuai dengan hasil wawancara penulis dengan Ketua BAMUS penyuluhan di lakukan rata-rata hanya dilaksanakan satu kali penyuluhan di masing-masing Korong. Dalam kegiatan ini pihak-pihak yang diundang terbatas, yaitu: perwakilan dari kelompok masyarakat yang ada di Nagari, yaitu: perwakilan dari tokoh-tokoh masyarakat seperti Niniak Mamak, Kaum Cadiak Pandai, Alim Ulama, Badan Permusyawaran Nagari dan perangkat Nagari dan Orang - orang yang berkepentingan lainnya.

\section{Rendahnya Kesadaran dan Pemahaman Hukum Masyarakat}

Kesadaran hukum masyarakat adalah merupakan keluaran (output) dari proses kegiatan penyuluhan yang mencapai tingkat optimalisasi ideal yang ditandai dengan timbulnya rasa untuk menghargai hukum. Jika mengacu pada Peraturan Menteri Hukum dan Hak Asasi Manusia RI Nomor M.01-PR.08.10 Tahun 2006 Tentang Pola Penyuluhan Hukum, kesadaran hukum masyarakat adalah nilai yang hidup dalam masyarakat adalah bentuk pemahaman dan ketaatan atau kepatuhan masyarakat terhadap norma hukum dan peraturan perundang-undangan yang berlaku.

Tingkat kesadaran dan kepatuhan masyarakat dalam mematuhi peraturan serta kurangnya pengetahuan dan pemahaman dari masyarakat yang menyebabkan tidak efektifnya suatu peraturan perundang-undangan. Masyarakat yang dimaksud yaitu masyarakat Nagari Katapiang yang belum begitu mengetahui Peraturan ini.

Rendahnya kesadaran hukum masyarakat dapat terlihat dari banyaknya masyarakat yang mengadakan orgen tunggal walaupun tanpa menggunakan Surat izin sebagaimana yang telah diatur oleh Peraturan Bupati no 13 tahun 2016. Orgen tunggal ini pokok pemicu timbulnya kerusuhan di dalam masyarakat karena orgen tunggal ini dirasa meresahkan, pertunjukannya sampai tengah malam dengan artis orgen yang berpenampilan tidak sesuai dengan norma adat dan agama, selain dari itu memancing 
kaum muda untuk mabuk-mabukan, judi-judian dan pada akirnya mereka tawuran. Hal ini dikarenakan ketidaktahuan dari masyarakat akan adanya Peraturan Bupati yang mengatur mengenai orgen tunggal ini.

\section{Keterbatasan Sumber Daya Manusia dalam Penegakan Hukum}

Keterbatasan sumber daya manusia mencakup dua aspek, yaitu aspek kualitas dan kuantitas. Aspek kualitas mencakup pemahaman seluruh penyelenggara pemerintahan di Nagari Katapiang, hingga tingkat Jorong terhadap Perda No. 3 Tahun 2009. Penegakan Perda No. 3 Tahun 2009 selama ini banyak bergantung pada Satpol PP di tingkat Kabupaten Padang Pariaman maupun tingkat kecamatan. Padahal kuantitas personil maupun anggaran mempengaruhi ruang gerak Satpol PP dalam melakukan pengawasan kepatuhan masyarakat terhadap Perda No. 3 Tahun 2009.

Keterbatasan tersebut tidak diimbangi dengan aparat pemerintahan di tingkatan paling rendah yakni Korong. Oleh karena itu keterbatasan tersebut harus diimbangi dengan kualitas penyelenggara pemerintahan di tingkat Korong dalam upaya-upaya meningkatkan pemahaman masyarakat terhadap Perda No. 3 Tahun 2009. Keberhasilan Perda ini tentunya bukan diukur dari makin meingkatnya pelanggaran yang ditangani oleh Polisi maupun Satpol PP. Indikator keberhasilan Perda No. 3 Tahun 2009 adalah ketika masyarakat tidak lagi melakukan pelanggaran-pelanggaran yang dilarang.

Kendala aparatur penegak hukum terkait yaitu, Wali Nagari beserta Ninik Mamak dan Wali Korong Nagari Katapiang. Aparatur penegak hukum ini memiliki peran yang sangat penting dalam memberikan arahan terhadap masyarakat. Salah satu tugasnya yaitu bertanggung jawab terhadap pelaksanaan Peraturan ini, baik berupa menghentikan secara lansung orgen tunggal, perjudian, minuman Keras dll yang telah melanggar Perda, maupun dalam sosialisasi aturan.Sejauh ini, Wali Nagari beserta Ninik Mamak dan Wali Korong memberikan arahan terhadap semua warga masyarakat Nagari Katapiang. Namun, karena kurang maksimalnya pengawasan dari pihak Wali Nagari Katapiang beserta Ninik Mamak dan Wali Jorong membuat masih banyaknya generasi muda yang melanggar.

Lemahnya pengawasan ini terjadi karena untuk mengawasi pelaksanaan Peraturan tersebut dibutuhkan banyak tenaga pengawas, sedangkan tenaga pengawas yang dimiliki hanya terbatas dalam hal jumlah dan fasilitas, maka dari itu diperlukan adanya pengawasan.Pengawasan dilakukan oleh pemerintah daerah terhadap segala kegiatan pemerintah nagari, agar penyelenggaraan pemerintah nagari dapat dilakukan dengan sebaik-baiknya.

\section{Tidak adanya sanksi dari Nagari untuk memberikan efek jera}

Dari hasil wawancara Penulis dengan beberapa orang responden rata-rata kendala yang mereka sampaikan penulis menyimpulkan bahwa tidak adanya sanksi dari Nagari untuk memberikan efek jera sehingga banyak para pemuda yang melakukan pelangaran norma meski telah ada peraturan daerah Padang Pariaman No. 3 Tahun 2009 tentang ketentraman dan Ketertiban umum ternyata sanksi yang tegas dari sumbang salah di nagari belum ada kalaupun ada tidak terealisasi dengan baik, karena ada beberapa faktor yang mempengaruhinya yakni sangat kurangnya landasan 
agama dalam diri khususnya anak-anak muda, kurangnya pembinaan yang dilakukan oleh keluarga, kurangnya maksimalnya kontroling serta peran dan perhatian dari lembaga Nagari terhadap warganya, ditambah lagi peran mamak terhadap kamanakan itu tidak ada,tidak berlakunya lagi istilah anak dipangku kamanakan dibimbiang.

\section{Rendahnya kesadaran Pemuda terhadap pelestarian dan aktualisasi adat- \\ istiadat serta nilai-nilai budaya}

Permasalahan-permasalahan yang terjadi di kalangan anak-anak muda Nagari Katapiang tersebut akibat dari berbagai faktor, diantaranya faktor minuman alkohol, kurangnya kontroling dari keluarga terhadap anaknya, kurangnya pembinaan yang dilakukan oleh kelurga dan pemerintah, kurang maksimalnya kontroling oleh pemerintah Nagari terhadap warganya, adanya oknum yang saling mengadu domba satu sama lain yang terjadi diantara pemuda, pengaruh mengkonsumsi narkoba, adanya rasa ketidak cocokan dalam pergaulan dan adanya penjimpanan amarah yang sudha lama di pendam; Masih rendahnya kesadaran pelestarian dan aktualisasi adat-istiadat dan nilai-nilai budaya. Hal ini disebabkan semakin meningkatnya pengaruh budaya luar.

6. Tidak dilibatkannya anak-anak muda (Generasi Muda) dalam pengambilan keputusan

Berdasarkan hasil wawancara penulis dengan seluruh pemuda yang dijadikan sampel didapatkan hasilnya bahwa mereka tidak mengetahui tentang adanya perda tersebut dikarenakan mereka tidak dilibatkan oleh Pemerintahan Nagari dalam pengambilan keputusan sehingga banyak dari mereka bersikap apatis acuh tak acuh dengan aturan pemerintahan yang telah ditetapkan melalui perudang-undangan, mereka juga mengatakan keterlibatan pemuda hanya sebatas pada ketua pemuda yang rata-rata umurnya lebih dari 40 tahun. Sementara yang penulis ketahui dari sumber bacaan yang disebut pemuda orang yang berumur 16 -30 tahun.

4.3. Upaya yang dilakukan untuk mengatasi kendala dalam Implementasi Peraturan Padang Pariaman No 3 tahun 2009 tentang Ketentraman dan Ketertiban Umum Dalam Rangka Membangun Generasi Muda Sadar Budaya Di Nagari Katapiang Kecamatan Batang Anai

\section{Menfokuskan Sosialisasi kepada Generasi Muda melalui peran serta} Kerapatan Adat Nagari

Komunikasi merupakan suatu hal yang sangat menentukan keberhasilan pencapaian tujuan dari pelaksanaan atau implementasi suatu program. Demikian halnya dengan Sosialisasi Perda No 3 Tahun 2009 tentang ketentraman dan ketertiban umum yang tentunya akan terlaksana secara efektif apabila komunikasi antara pihak- 
pihak yang terkait berjalan dengan baik. Komunikasi yang terjalin dengan baik antara pihak Pemerintahan Nagari selaku pelaksana Kebijakan dengan masyarakat selaku sasaran utama dari Perda tersebut menjadi hal yang mutlak diperlukan demi tercapainya keefektifan pelaksanaan Ketentraman dan Ketertiban ini. Bentuk komunikasi di sini tentunya dapat diinterpretasikan melalui proses sosialisasi Kebijakan kepada masyarakat yang merupakan sasaran dari Kebiakan yang bersangkutan. Sosialisasi menjadi kunci utama keberhasilan suatu program dalam mencapai tujuan serta sasaran yang diharapkan. Melalui proses sosialisasi yang efektif kepada masyarakat, suatu program akan dengan mudah mencapai keberhasilan dalam pelaksanaannya. Hal ini dapat terjadi karena semakin baik proses sosialisasi dari suatu program maka akan semakin baik pula pemahaman masyarakat akan konsep dan tujuan dari program tersebut. Dengan begitu masyarakat teruma para pemuda akan semakin terdorong untuk mengakses informasi lebih jauh mengenai kebijakan ini serta ambil bagian dalam Kebijkan yang dilaksanakan oleh pemerintah tersebut. Sebagai pelaksana kebijakan dari pemerintah Daerah melakukan sosialisasi kepada masyarakat Dalam mensosialisasikan aturan ini, ada upaya yang dilakukan yakni, sosialisasi secara lisan, dan sosialisasi secara tulisan. Sosialisai secara lisan disampaikan kepada masyarakat di masjid-masjid dengan pendekatan agama dan adat. Sedangkan sosialisasi secara tulisan dilakukan dengan menyebar surat himbauan dan ditempel di tempat-tempat umum. Sosialisasi ini, Wali Nagari memberdayakan Wali Korong yang ada di wilayah Pemerintahan Nagari Katapiang untuk mensosialisasikan aturan ini kepada masyarakat. Selain itu, Wali Nagari juga memberdayakan tokoh adat dan tokoh agama dalam sosialisasi ini.serta meningkatkan peran serta kedudukan lembaga Kerapatan Adat Nagari (KAN) dalam struktur pemerintahan adat Minangkabau sebagai Lembaga Adat masih diakui oleh masyarakatnya sebagai lembaga penyelesaian masalah anak kemenakan termasuk yang berkaitan dengan masalah Sumbang Salah.

\section{Melakukan Pembinaan dan Pengawasan Ketentraman dan Ketertiban kepada Masyarakat terutama kepada Anak-Anak Muda Nagari.}

Pembinaan dimaksudkan sebagai upaya untuk meningkatkan kesadaran masyarakat, di samping meningkatkan Kesadaran dan Pengetahuan masyarakat tentang pelaksanaan peraturan daerah padang pariaman no 3 tahun 2009 mengenai ketentraman dan ketertiban umum. Selain pembinaan dan pengawasan dari pemerintahan nagari, perlu peran mamak terhadap kemenakan itu ditingkatkan, kemudian kaum niniak mamak dan cadiak pandai selalu mengingatkan apa yang pantas dan tidak pantas untuk dilakukan, perlu pengayoman dari alim ulama sehingga kehidupan itu bisa seimbang antara dunia dan akhirat, sebagai bentuk pembinaan dari bundo kandung diminangkabau perlu bimbingan dan nasihat-nasihat yang baik untuk mereka dan yang terpenting lagi pembinaan yang dilakukan dalam kaum sapasukuan sejak dini sebagai pengontrol moral masa depan, supaya para generasi muda mengerti tentang aturan yang berlaku di Pemerintah maupun di nagari itu sendiri.

Selanjutnya Memperkuat akidah para pemuda Akidah merupakan pondasi dasar yang harus dimiliki oleh para generasi muda untuk meneruskan nilai budaya luhur bangsa Indonesia. Kuat dan tidaknya pondasi ini juga akan menentukan seberapa kuat 
karakter suatu bangsa. Bila para generasi mudanya sudah tidak memiliki jati diri yang kuat maka budaya asing pun akan mudah dengan leluasanya menggeser budaya suatu daerah. dan sebaliknya jika suatu daerah memiliki jatidiri yang kuat maka akan sangat sulit budaya asing untuk bisa masuk, apalagi mengantikan budaya daerah tersebut.

Maka dari itu generasi muda seharusnya lebih menguatkan jatidiri dan kecintaanya pada suatu budaya yang akan mereka warisi nantinya.

\section{Mengembangkan Kualitas SDM melalui peningkatan Peran Lembaga Nagari}

Sumber daya manusia memegang peranan penting dalam proses keberhasilan suatu Program karena Sumber Daya Manusia adalah potensi manusiawi sebagai penggerak organisasi dalam mewujudkan eksistensinya. Sumber daya manusia adalah suatu proses mendayagunakan manusia sebagai tenaga kerja secara manusiawi, agar potensi fisik dan psikis yang dimilikinya berfungsi maksimal bagi pencapaian tujuan organisasi.

Salah satu upaya untuk mengatasi keterbatasan sumber daya manusia itu sendiri adalah meningkatkan peran dan tugas Wali Nagari sangatlah kompleks dalam melaksanakan tugas umum pemerintahan di lingkungan. Hal ini khususnya berkaitan dengan tugas-tugas atributif dalam bidang koordinasi pemerintahan terhadap seluruh perangkat, penyelenggaraan ketentraman dan ketertiban, penegakan peraturan perundangan, pembinaan Nagari. Oleh karena itu, kedudukan Wali Nagari berbeda dengan kepala instansi pemerintahan lainnya di wilayah Kanagarian karena penyelenggara tugas instansi tersebut harus berada dalam koordinasi Nagari. Dalam organisasi pemerintahan, koordinasi merupakan hal penting yang harus diterapkan. Seorang pemimpin akan dinilai baik apabila koordinasi yang dilakukannya berjalan dengan baik. Koordinasi yang dilakukan Oleh Nagari Katapiang dalam upaya penyelenggaraan ketentraman dan ketertiban umum merupakan hal yang sangat penting dilakukan.

\section{Revitalisasi (mengiatkan) Organisasi Kepemudaan Nagari}

Tujuannya adalah untuk menumbuhkan dan melestarikan nilai-nilai yang tertanam dalam kebudayaan minangkabau sesuai dengan falsafah adat "adat basandi sarak sarak basandi kitabullah. Seiring dengan perkembangan zaman anak-anak muda minangkabau khususnya anak Nagari Katapiang yang sudah tidak paham lagi dengan adat istiadat yang berlaku kebanyakan dari mereka hura-hura seperti balapan motor liar, perjudian, mabuk-mabukan, membuat kegaduhan ditengah masyarakat dan lain sebagainya sehingga menganggu ketentraman dan ketertiban umum, maka dari itu dicarikanlah solusinya salah satunya yakni dengan mengiatkan organisasi kepumudaan seperti acara "baretong di nan tarang". Baretong ini menampilkan kesenian-kesenian dari sangar-sangar kesenian tradisional yang dikenal oleh masyarakat katapiang dengan nama "tabuah basa". Acara ini didukung oleh pemerintah nagari sebagai wujud nyata untuk meningkatkan peran anak-anak nagari dalam meningkatkan kesadaran budaya, bukan hanya itu pemerintah nagari juga mendukung organisasi-organisasi lainnya seperti organisasi grup pidato adat "sekapur sirih" dan organisasi-organisasi lainnya yang diharapkan mampu untuk mengiatkan kepemudaan dalam berorganisasi dengan 
begitu usaha ini mampu untuk meminagkan orang minangkabau yang artinya mampu menjadi pribadi orang minangkabau sesungguhnya.

Dari hasil wawancara penulis tersebut penulis mengharapkan dalam merevitalisasi atau mengiatkan organisasi kepemudaan seharusnya ada pamong budaya Nagari yang mendampingi para anak-anak muda untuk giat dalam organisasi kepemudaan yang dibentuk oleh Nagari sendiri dengan meswadayakan masyarakat dengan memberikan imbalan secara sukarela dari seluruh kepala rumah tangga atau masyarakat atau bisa juga dimasukkan dalam anggaran belanja Nagari.

\section{Melaksanakan Koordinasi yang baik dengan Polisi, Satpol PP dan Masyarakat.}

Sesuai dengan hasil wawancara penulis dengan wali nagari tentang upaya untuk mengatasi kendala yang ada yakni tentang tidak adanya sangsi dari nagari yang memberi efek jera, maka penulis menyimpulkan bahwa salah satu upayanya adalah melakukan koordinasi dengan polisi, satpol pp dan masyarakat setempat misalnya dalam acara hiburan yang diadakan oleh pemuda maka, perlu koordinasi dan kerjasama dengan satpol pp untuk mengatasi keamanan selama acara berlangsung apabila terjadi kericuhan yang tidak bisa ditangani oleh satpol pp maka polisi akan turun tangan mengatasi kejadian tersebut. Contoh lainnya masyarakat yang akan mengadakan orgen tunggal untuk acara kenduri atau yang sering disebut baralek maka perlu izin dari wali nagari apabila tidak mengizinkan maka tidak boleh dilangsungkan apabila diizinkan ada aturan-aturan yang harus dipatuhi sesuai dengan Peraturan Bupati No 13 tahun 2016 tentang penertiban orgen tunggal.

6. Meningkatkan Partisipasi Pemuda dengan memberikan kesempatan kepada Generasi Muda untuk berpartisipasi dalam Nagari.

Tidak dilibatkan pemuda dalam pengambilan keputusan menjadi persoalan dalam nagari khususnya pada nagari katapiang dalam hal pelaksanaan Perda No 9 tahun 2009 tentang ketertiban dan ketentraman umum maka perlu ada solusi yakni memberikan masukan maupun dalam tahap evaluasi kebijakannya sehingga pemuda paham tentang hukum yang berlaku.

Keberhasilan penyelenggaraan pembangunan juga tidak terlepas dari adanya partisipasi aktif Pemuda. Pemuda sebagai generasi penerus bangsa yang diharapkan dapat menghayati, memahami, serta mengamalkan nilai - nilai luhur perjuangan bangsa. Generasi pemuda sebagai bagian dari bangsa Indonesia memiliki tanggung jawab nasional untuk menumbuhkan dan mengembangkan kesadaran kaum muda sebagai suatu bangsa yang berdasarkan pada pancasila dan UUD1945, serta berpedoman pada haluan negara dengan ikut mengisi kemerdekaan, mencerdaskan kehidupan bangsa dan mempercepat pembangunan nasional demi kemajuan dan kesejahteraan masyarakat. Partisipasi pemuda dalam 21pembangunan berarti memberikan kesempatan pada pemuda untuk memenuhi berbagai keinginan dan harapan-harapanya.

\section{KESIMPULAN DAN SARAN}

\subsection{KESIMPULAN}


Dari uraian-uraian, penjelasan, pendapat dan analisis data hasil wawancara yang telah ditemukan pada Bab sebelumnya, maka pada bab ini dilakukan perumusan kesimpulan dari hasil pembahasan terhadap permasalahan tentang Implementasi Peraturan Daerah Padang Pariaman No 3 tahun 2009 tentang Ketentraman dan Ketertiban Umum dalam rangka membangun Generasi Muda yang Sadar Budaya di Nagari Katapiang Kecamatan Batang Anai, Adapun hasil kesimpulan tersebut sebagai berikut :

1. Peraturan Daerah Kabupaten Padang Pariaman No. 3 Tahun 2009 yang mengatur tentang ketentraman dan Ketertiban Umum Nagari Katapiang dilaksanakan dalam tiga tahapan kegiatan yang berlangsung secara terus menerus, yaitu: Tahap Sosialisasi, Tahap Pelaksanaan dan Tahap Monitoring. pertama tahapan sosialisasi ada dua yakni sosialiasi secara langsung dan tidak langsung. Secara langsung dilakukan dalam bentuk penyuluhan ditingkat kanagarian, di nagari katapiang melaksanakan penyuluhan hanya satu kali dan tidak melibatkan masyarakat keseluruhan teruma anak-anak muda. Secara tidak langsung dilakukan melalui media elektronik, pemasangan reklame dan penyebaran leaflet tapi pada kenyataannya tidak ada penyebaran leaflet maupun reklame dinagari katapiang tentang peraturan ini hanya saja dilakukan melalui mulut ke mulut dari masyarakat. Kedua tahapan pelaksanaannya belum terlaksana dengan baik karena masyarakat terutama pada generasi muda belum memiliki kesadaran akan pentingnya mewujudkan keamanan dan ketertiban dalam masyarakat. yang ke tiga tahap monitoring pada tahap ini seharusnya dilakukan setiap akir tahun tapi pada kenyaannya tidak ada Pemerintahan Daerah maupun Pemerintahan Nagari melakukan Monitoring untuk mengetahui sejauh mana Perda tersebut telah dilaksanakan.

2. Kendala yang ditemui dalam Implementasi Kebijakan Padang Pariaman No 3 tahun 2009 tentang Ketentraman dan Ketertiban Umum Dalam Rangka Membangun Generasi Muda Sadar Budaya di Nagari Katapiang Kecamatan Batang Anai adalah:

1) Kurangnya Sosialisasi

2) Rendahnya kesadaran dan pemahaman hukum masyarakat

3) Keterbatasan sumber daya manusia dalam penegakan hukum

4) tidak adanya sanksi dari nagari untuk memberikan efek jera

5) Rendahnya kesadaran pemuda terhadap pelestarian dan akulturasi adat istiadat serta nilai-nilai budaya

6) tidak dilibatkannya anak-anak muda (Generasi Muda) dalam pengambilan keputusan

3. Upaya yang dilakukan untuk mengatasi kendala dalam Implementasi Kebijakan Padang Pariaman No 3 tahun 2009 tentang Ketentraman dan Ketertiban Umum Dalam Rangka Membangun Generasi Muda Sadar Budaya Di Nagari Katapiang Kecamatan Batang Anai adalah :

1) Memfokuskan Sosialisasi kepada generasi muda melalui peran serta Kerapatan Adat Nagari 
2) Melakukan pembinaan dan pengawasan ketentraman dan ketertiban kepada masyarakat terutama anak-anak muda Nagari

3) Mengembangkan kualitas SDM melalui peningkatan peran lembaga Nagari

4) Revitalisasi (mengiatkan) organisasi kepemudaan Nagari

5) Melakukan Koordinasi yang baik dengan Polisi, Satpol PP dan Masyarakat

6) Meningkatkan Partisipasi Pemuda dengan memberikan kesempatan kepada generasi muda untuk berpartisipasi dalam Nagari.

\subsection{SARAN}

1. Untuk Institusi Pemerintahan baik ditingkat tertinggi maupun terendah seperti Korong/Jorong lebih memperhatikan anak-anak muda dengan memberikan kepada mereka kesempatan dan ruang publik untuk berpartisipasi dalam pengambilan keputusan serta memberikan pemahaman melalui pelatihanpelatihan untuk meningkatkan rasa memiliki dan kecintaan terhadap budaya Indonesia.

2. Untuk lembaga Adat peran serta dalam Nagari seharusnya lebih ditingkatkan karena selain peran dari keluarga. Niniak mamak, alim ulama, cadiak pandai memang harus benar-benar menanamkan nilai-nilai adat istiadat, walaupun zaman sudah tidak sama seperti yang dulu dengan seiring perkembangan zaman dan kecangihan teknologi maka perlu ada ide-ide baru, inovasi-inovasi baru untuk meminangkan anak-anak minangkabau.

3. Untuk para pemuda hendaknya kita mencintai dan memelihara budaya serta kearifan lokal yang kita miliki jangan sampai jati diri kita sebagai orang minangkabau tergantikan dengan budaya asing yang merusak moral kehidupan anak Nagari. 


\section{Daftar Pustaka}

Arifin. (2010). Kinerja Pegawai Fungsi dari kemampuan dan lingkungan. Yogyakarta : Teras.

Fakih, M. (2003). Runtuhnya Teori Pembangunan dan Globalisasi . Yogyakarta: Pustaka Pelajar.

Giddens, A. (2001). Runaway World . Jakarta : Gramedia.

koentrajanigrat. (2007). Manusia dan Kebudayaan di Indonesia . Jakarta: Djambatan. Koentrajanigrat. (2007). Manusia dan Kebudayaan di Indonesia. Jakarta: Djambatan. Koentrajaningrat. (1975). Manusia dan Kebudayaan di Indonesia. Jakarta: Jambatan . Maleong, L. J. (2002). Metodologi Penelitian Kuantitatif. Bandung : Rosda.

Nawawi, H. (2012). Metode Researrch (penelitian ilmiah). Jakarta: Bumi aksara .

Tangkilisan, Hessel Nogi. (2003). Implementasi Kebijakan Publik . Jakarta: Lukman Offset. 